\title{
Soil moisture depletion and ground water use by bed planted barley as influenced by cultivars, crop geometry and moisture regimes
}

\author{
Naveen Kumar*, Suresh Kumar, Parveen Kumar and Meena Sewhag \\ Department of Agronomy, CCS Haryana Agricultural University, Hisar-125004 (Haryana), INDIA \\ *Corresponding author. E-mail: nknaveenroyal@gmail.com
}

Received: October 23, 2016; Revised received: February 28, 2017; Accepted: July 22, 2017

\begin{abstract}
A field experiment was conducted during rabi season 2011-2012 at Research Farm, CCS Haryana Agricultural University, Hisar, Haryana (India) to study the periodic soil moisture depletion and ground water use by bed planted barley as influenced by cultivars, crop geometry and moisture regimes under shallow water table conditions. The experiment was laid out in split plot design with three replications keeping combinations of three cultivars viz., $\mathrm{BH} 393, \mathrm{BH} 902$ and $\mathrm{BH} 885$ and two crop geometries viz 2 rows per bed and 3 rows per bed $(70 \mathrm{~cm}$ wide with $40 \mathrm{~cm}$ top and $30 \mathrm{~cm}$ furrow) in main plots and three moisture regimes (irrigation at IW/CPE 0.3, $0.4 \& 0.5$ ) in sub plots. The results revealed that maximum soil moisture depletion $(105 \mathrm{~mm})$ and ground water contribution $(62 \mathrm{~mm})$ were recorded in $\mathrm{BH}$ 902, followed by $\mathrm{BH} 393$ and $\mathrm{BH}$ 885. Among crop geometries, soil moisture depletion (96.6 $\mathrm{mm}$ ) and ground water contribution $(61 \mathrm{~mm})$ were recorded higher in 3 rows per bed than 2 rows per bed. Among three moisture regimes, the soil moisture depletion $(108 \mathrm{~mm})$ and ground water contribution $(65 \mathrm{~mm})$ decreased with increase in moisture regime from irrigation at IW/CPE 0.3 to irrigation at IW/CPE 0.4 or 0.5
\end{abstract}

Keywords: Barley, Bed planting, Ground water use, Moisture regimes, Soil moisture depletion

\section{INTRODUCTION}

Barley (Hordeum vulgare L.) is a dual purpose crop grown for fodder as well as grain purpose. It is the fourth-largest cereal crop in the world, with a share of seven percent of the global cereals production and 15 percent of coarse grains consumption, used in animal feed, malting and food products. Barley malt has wider application in the field of food, beverages and distilleries pharmaceuticals. It is also used as a raw material for malted food like Bourn vita, Horlicks, Protein based feed product, biscuit, chocolates, beer, whisky, brandy, industrial alcohol and vinegar. World over, barley is cultivated in about 49.6 million hectares area producing 144 million tones with a productivity of $2912 \mathrm{~kg} / \mathrm{ha}$ (FAO, 2016). In India, barley is grown on 0.69 million hectares area with 1.8 million tonnes production and average yield of $2720 \mathrm{~kg} / \mathrm{ha}$ and it is largely confined to North-West region (Anonymous, 2016). Despite low production of barley, India is self sufficient in barley, besides annual export of 0.1-0.2 million tonnes annually. Barley is commonly grown in India under restricted irrigation conditions, following conventional system of flat sowing and flooded irrigation, which is conducive to excessive irrigation water use, downward leaching of native and applied nutrients, periodic aeration stress and high mechanical resistance. The research activities initiated about 30 years ago on bed and furrow system in ICRISAT and during recent years, furrow irrigated raised bed plant- ing system (FIRBS) has proved to be one of the important components of low cost sustainable production system for crop production in several parts of the world, including India (Rajanna et al., 2016).

Soil moisture is one of the most important factors which influence the availability of water and nutrients to plants. Interval of irrigation application greatly influences the soil moisture and hence, the grain yield of barley. In areas with shallow water table, the ground water contributes to a significant amount of water use for the crop need. Different cultivars may response differently to shallow water table and irrigation intervals. The desired information regarding response of barley cultivars to crop geometry and irrigation intervals in bed panted system under shallow water table is lacking (Kumar, 2013). Keeping this in view, the present investigation was carried out to assess the periodic soil moisture depletion and ground water use by bed planted barley cultivars as influenced by crop geometry and moisture regimes under shallow water table conditions.

\section{MATERIALS AND METHODS}

The experiment was conducted during rabi season 2011-12 at research farm of CCS Haryana Agricultural University, Hisar, Haryana (India) situated at $29^{\circ} 10^{\prime} \mathrm{N}$ latitude and $75^{\circ} 46^{\prime} \mathrm{E}$ longitude at an elevation of $215.2 \mathrm{~m}$ above mean sea level in a semi-arid climate. The texture of the surface soil of the experimental field was sandy loam with basic infiltration rate of $4.4 \mathrm{~mm} /$ 
Table 1. Soil moisture depletion $(\mathrm{mm})$ by barley as influenced by cultivars, row spacing and moisture regimes under raised bed planting.

\begin{tabular}{|c|c|c|c|c|c|}
\hline \multirow[t]{2}{*}{ Treatments } & \multicolumn{5}{|c|}{ DAS (days after sowing) } \\
\hline & 0-30 & $30-60$ & $60-90$ & At maturity & Total \\
\hline \multicolumn{6}{|l|}{ Cultivars } \\
\hline BH 393 & 9.6 & 36.5 & 30.7 & 19.2 & 96.0 \\
\hline BH 902 & 10.5 & 39.9 & 33.6 & 21.0 & 105.0 \\
\hline BH 885 & 8.3 & 31.5 & 26.6 & 16.6 & 83.0 \\
\hline \multicolumn{6}{|l|}{ Row spacing } \\
\hline 2 rows per bed & 9.3 & 35.2 & 29.7 & 18.5 & 92.7 \\
\hline 3 rows per bed & 9.7 & 36.7 & 30.9 & 19.3 & 96.6 \\
\hline \multicolumn{6}{|c|}{ Moisture regimes : Irrigation at } \\
\hline $\mathrm{IW} / \mathrm{CPE}=0.3$ & 9.5 & 36.0 & 36.6 & 25.9 & 108.0 \\
\hline $\mathrm{IW} / \mathrm{CPE}=0.4$ & 9.4 & 35.4 & 27.3 & 15.9 & 88.0 \\
\hline $\mathrm{IW} / \mathrm{CPE}=0.5$ & 9.5 & 36.4 & 27.1 & 15.0 & 88.0 \\
\hline
\end{tabular}

Table 2. Soil moisture extraction pattern $(\mathrm{mm})$ of barley as affected by cultivars, row spacing and moisture regimes under raised bed planting.

\begin{tabular}{|c|c|c|c|c|}
\hline \multirow[t]{2}{*}{ Treatments } & \multicolumn{4}{|c|}{ Soil depth (cm) } \\
\hline & $0-15$ & 15-30 & $30-60$ & $60-90$ \\
\hline \multicolumn{5}{|l|}{ Cultivars } \\
\hline BH 393 & 44.9 & 30.8 & 15.0 & 5.3 \\
\hline BH 902 & 49.4 & 34.3 & 15.9 & 5.5 \\
\hline BH 885 & 38.6 & 26.1 & 13.4 & 4.8 \\
\hline \multicolumn{5}{|l|}{ Row spacing } \\
\hline 2 rows per bed & 43.1 & 29.6 & 14.6 & 5.5 \\
\hline 3 rows per bed & 45.4 & 31.2 & 15.0 & 5.1 \\
\hline \multicolumn{5}{|c|}{ Moisture regimes : Irrigation at } \\
\hline $\mathrm{IW} / \mathrm{CPE}=0.3$ & 49.9 & 33.9 & 18.0 & 6.2 \\
\hline $\mathrm{IW} / \mathrm{CPE}=0.4$ & 41.2 & 28.4 & 13.5 & 4.9 \\
\hline $\mathrm{IW} / \mathrm{CPE}=0.5$ & 41.6 & 28.7 & 13.1 & 4.6 \\
\hline
\end{tabular}

Table 3. Ground water contribution $(\mathrm{mm})$ in barley as influenced by cultivars, row spacing and moisture regimes under raised bed planting.

\begin{tabular}{lccccc}
\hline Treatments & \multicolumn{3}{c}{ DAS (days after sowing) } \\
\cline { 2 - 6 } & $\mathbf{0 - 3 0}$ & $\mathbf{3 0 - 6 0}$ & $\mathbf{6 0 - 9 0}$ & At maturity & Total \\
\hline Cultivars & 6.0 & 22.8 & 19.2 & 12.0 & 60.0 \\
BH 393 & 6.2 & 23.6 & 19.8 & 12.4 & 62.0 \\
BH 902 & 5.8 & 22.0 & 18.6 & 11.6 & 58.0 \\
BH 885 & & & & & \\
Row spacing & 5.9 & 22.4 & 18.9 & 11.8 & 69.0 \\
2 rows per bed & 6.1 & 23.2 & 19.5 & 12.2 & 61.0 \\
3 rows per bed & 6.0 & 22.7 & 22.8 & 13.5 & 65.0 \\
Moisture regimes $:$ Irrigation at & 23.1 & 17.5 & 11.3 & 58.0 \\
IW/CPE =0.3 & 6.1 & 22.6 & 17.3 & 11.2 & 57.0 \\
IW/CPE $=0.4$ & 5.9 & & & \\
IW/CPE $=0.5$ & & & & & \\
\hline
\end{tabular}

h. It contained 20.2 and 7.5 per cent moisture on weight basis, at -0.03 and $-1.5 \mathrm{MPa}$ respectively, as analyzed by Pressure membrane apparatus (Richards, 1954), and available soil moisture in $0-90 \mathrm{~cm}$ soil layer was $16 \mathrm{~cm}$. The soil was low in available $\mathrm{N}(182 \mathrm{~kg}$ / ha), medium in available $\mathrm{P}(18 \mathrm{~kg} / \mathrm{ha})$ and high in available K (285 kg/ha). The water table fluctuated between $136 \mathrm{~cm}$ at sowing to $145 \mathrm{~cm}$ at maturity. The pan evaporation during the four periods i.e. sowing to $30 \mathrm{DAS}, 31$ to $60 \mathrm{DAS}, 61$ to $90 \mathrm{DAS}$ and 91 to ma- turity was 20.4, 53.4, 77.9 and $159.1 \mathrm{~mm}$, respectively While, total rainfall received was $21.7 \mathrm{~mm}$ (Fig. 1). The experiment was laid out in split plot design with treatments combinations of three cultivars (BH 393, BH 902 and $\mathrm{BH} 885$ ) and two crop geometries (2 rows and 3 rows per bed $70 \mathrm{~cm}$ wide bed with $40 \mathrm{~cm}$ top and $30 \mathrm{~cm}$ furrow) in main plots and three moisture regimes (irrigation at IW/CPE 0.3, 0.4 and 0.5) in sub plots each replicated thrice. The experiment was sown on 11 December 2011 with the help of bed planter 


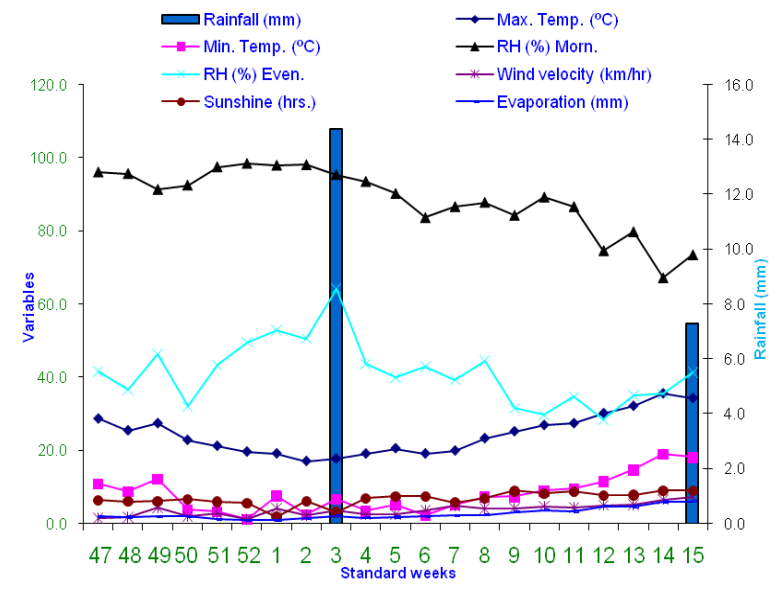

Fig. 1. Mean weekly weather data during the rabi crop season 2011-2012 (CCS HAU, Hisar).

using recommended seed rate. Irrigations were applied as per treatments based on IW/CPE in individual plots. The IW/CPE ratios were calculated based on depth of irrigation depth and the cumulative pan evaporation during the particular period. Only one poet-sown irrigation $(64 \mathrm{~mm})$ was applied in the treatments IW/CPE 0.3 but two irrigations were applied in each treatment IW/CPE $0.4(116 \mathrm{~mm})$ and IW/CPE $0.5(117 \mathrm{~mm})$. Soil samples were taken from $0-15,15-30,30-60$ and $60-90 \mathrm{~cm}$ depth to monitor the profile moisture status of the active root zone gravimetrically at sowing, before and after each irrigation and at harvest. The moisture in entire root zone $(90 \mathrm{~cm})$ was computed by changes in the soil moisture content in the root zone during the crop period. Ground water contribution was calculated by estimating the flux density of the soil water from ground water table to root zone using Darcy's law for steady state conditions as proposed by Giesel et al. (1972) assuming that the flux entering the lower layer of the root zone is the potential contribution.

\section{RESULTS AND DISCUSSION}

Periodic soil moisture depletion: In general, the moisture depletion from soil by barley crop planted on raised beds was relatively higher between 30 to 60 DAS, due to higher crop water requirement, but non application of irrigation water (Table 1). Among the cultivars, BH 902 depleted maximum soil moisture at all stages followed by BH 393 due to increased evapotranspiration demand owing to its higher growth and LAI (Kumar et al., 2012). The cultivar BH 885 depleted minimum soil moisture at all the stages due lower growth habit of the cultivator. Planting of barley on raised beds with 3 rows per bed depleted higher soil moisture than 2 rows per bed at all crop growth stages. This was due to higher crop water requirement owing to increased LAI and hence increased ET demand. Among different moisture regimes, the soil moisture depletion pattern remained same till 60 DAS because no irrigation treatment was applied till that time. But, the depletion of soil moisture was higher with irrigation at IW/CPE 0.3 from 60 DAS to till harvest, which decreased with increasing moisture regime to irrigation at IW/CPE 0.4 and 0.5. Under deficit irrigation moisture regime (IW/CPE 0.3) relatively less amount of irrigation water was applied and the crop extracted more water from the soil profile to meet its metabolic requirement. These results are in corroboration with Kumar et al. (2011) in wheat crop under sandy loam textured soil of semi-arid tropics and Bandy opadhyay \& Mallick (2003) in sandy loam (Typic Fluvaquent) soil and shallow water table conditions under conventional flat sowing system of wheat.

From the depth-wise soil moisture extraction patternwas higher from the uppermost soil layers (0-30) irrespective of treatments due to maximum root mass and root growth activity in this layer (Table 2). Moisture extraction was lower from deeper soil layers. Moreover, the surface soil, being exposed to direct radiation, was subjected to higher loss of water through evaporation. Similar findings were reported in wheat by Maurya and Singh (2008) at Faizabad (UP) under irrigated conditions in silt loam soil.

Periodic ground water contribution: The ground water contribution to meet out the crop water requirement of barley planted on raised beds was higher at 30 to 60 DAS followed by 60 to 90 DAS irrespective of treatments as irrigation was not applied till that stage and crop water requirement was high due to growth of the crop (Table 3). Among cultivars, BH 902 used maximum ground water followed by $\mathrm{BH} 393$ and $\mathrm{BH} 885$ at all crop growth stages due to high ET demand for higher crop growth. Planting of barley on raised beds with 3 rows per bed resulted in higher ground water contribution than 2 rows per bed at all crop growth stages. Higher depletion of ground water in 3 rows per bed may be to meet out the higher ET demand to achieve higher growth and yield. The ground water contribution pattern remained similar till 60 DAS among different moisture regimes as no irrigation was applied till that time. But it was higher with irrigation at IW/CPE 0.3 from 60 DAS to maturity and decreased with increase in moisture regime to IW/CPE 0.4 or 0.5 . This may be to compensate the low water supply through irrigations under deficit irrigation (IW/CPE 0.3 ) as he roots of plants penetrate deeper to meet out the ET demand for growth. Similar results were reported by Kumar et al. (2011) in wheat crop under sandy loam textured soil of semi-arid tropics.

\section{Conclusion}

In bed planted barley BH 902 cultivar used maximum soil moisture and ground water. While, planting of barley with 3 rows per bed depleted higher soil mois- 
ture and ground water than 2 rows per bed. Lesser irrigation water was applied in irrigation at IW/CPE 0.3, but the bed plated barley crop extracted more water from the soil profile and ground water to meet the crop water requirement under shallow water table conditions.

\section{REFERENCES}

Anonymous (2016). Directorate of Economics and Statistics, Ministry of Agriculture and Farmers Welfare, India.

Bandyopadhyay, P.K. and Mallick, S. (2003). Actual evapotranspiration and crop coefficients of wheat (Triticumaestivum) under varying moisture levels of humid tropical canal command area. Agric. water mgmt. 59: 33-47.

CCS HAU (2012). Department of Agricultural Meteorology CCS HAU, Hisar, India.

FAO (2016). FAOSTAT , FAO, Rome, Italy.

Giesel, W.V., Ranger, M. and Strebel, O. (1972). Berechnung des kapillaren Ausfstiegesausdem Grundwasser in den Wurzelraumvnderstationoir. Bedigvng. Z. Pflan-
zenernaehrBodenkd. 132: 17-30.

Kumar, N (2013). M.Sc. Thesis. CCS Haryana Agricultural University, Hisar, India.

Kumar, N., Kumar, S and Arya, R.K. (2012). Effect of cultivars and plant geometry on dry fodder production of barley under various moisture regimes on raised bed planting. Forage Res. 38 (3): 174-76.

Kumar, S., Dhindwal,A.S., Sewhag,M., and Kumar,P.(2011). Periodic soil moisture and ground water use by wheat under shallow water table conditions as influenced by preceding crops, planting methods and moisture regimes. Haryana J Agron. 27: 22-25.

Maurya, R.K and Singh, G.R. (2008). Effect of crop establishment methods and irrigation schedules on wheat production, moisture depletion pattern, consumptive use and crop water-use efficiency.Indian J. Agri. Sci.80(10): 830-833.

Rajanna, G.A. , Dhindwal, A.S. and Nanwal, R.K. (2016). Irrigation scheduling and crop establishment techniques in cluster bean-wheat sequence irrigation scheduling and crop. Ann. Agric. Res. New Se,ies 37 (4) : 335-346. 